\title{
Salinity and Soil Type Effects on Emergence and Growth of Pepper Seedlings
}

\author{
Genhua Niu ${ }^{1}$ and Denise S. Rodriguez \\ Texas AgriLife Research Center at El Paso, Texas A\&M System, El Paso, TX \\ 79927
}

Rosa Cabrera
El Paso Community College, Research Initiative for Scientific Enhancement
Program, El Paso, TX 79925

John Jifon

Texas AgriLife Research Center at Weslaco, Texas A\&M System, Weslaco, TX 78596

\section{Daniel Leskovar \\ Texas AgriLife Research Center at Uvalde, Texas A\&M System, Uvalde, TX 78801}

\section{Kevin Crosby \\ Department of Horticultural Sciences, Vegetable and Fruit Improvement Center, Texas A\&M University, College Station, TX 77845}

\section{Additional index words. Capsicum annuum, salinity tolerance, soil type}

\begin{abstract}
High soil salinity often results in poor stand establishment, reduced plant growth, and reduced yield of many horticultural crops such as peppers (Capsicum annuиm). We investigated the effects of soil salinity and soil type on seedling emergence and growth of four commercial peppers ('NuMex Joe E. Parker', 'NuMex Nematador', 'NuMex Primavera', and 'Jupiter') in greenhouse experiments. Seeds were sown in either a loamy sand or a silt loam soil in pots and irrigated with saline solutions at electrical conductivity of 0.9 (tap water), 3.0, or $6.0 \mathrm{dS} \cdot \mathrm{m}^{-1}$ (Expt. 1) or at 0.0 [reverse osmosis (RO) water], 0.9, or $1.5 \mathrm{dS} \cdot \mathrm{m}^{-1}$ (Expt. 2). No seedling emergence was observed in treatments irrigated with 3.0 or $6.0 \mathrm{dS} \cdot \mathrm{m}^{-1}$ solutions. The salinity at the top soil layer increased linearly with time when subirrigated with tap and saline solutions in both soil types, whereas no substantial increase in soil salinity was found when subirrigated with RO water or overhead irrigation with tap water. Salt accumulation at the top soil layer was greater in loamy sand than in silt loam. Seedling emergence percent subirrigated with RO water ranged from $70 \%$ to $80 \%$ in loamy sand and $45 \%$ to $70 \%$ in silt loam, depending on pepper cultivars. When subirrigated with tap water and saline solutions, the emergence percent ranged from $0 \%$ to $60 \%$, depending on pepper and soil types. In Expt. 3, seedlings were germinated in commercial potting mix and grown in 1.8-L pots containing commercial potting mix. Saline solution treatments of 1.4 (control, nutrient solution), 2.1, 2.9, 3.5, or $4.2 \mathrm{dS} \cdot \mathrm{m}^{-1}$ were initiated when seedlings had 11 to 13 leaves. Five weeks after initiating saline water irrigation, the reduction in shoot dry weight was greater in 'Jupiter' and 'NuMex Primavera' as compared with 'NuMex Joe E. Parker' and 'NuMex Nematador', but the differences were small.
\end{abstract}

Soil salinity is a common problem in agricultural regions of the southwestern United States as a result of low rainfall, high evapotranspiration, and poor quality of irri-

\footnotetext{
Received for publication 30 Apr. 2010. Accepted for publication 14 June 2010.

We gratefully acknowledge the financial support from National Institute of Food and Agriculture, U.S. Department of Agriculture under Agreement No. 2009-34461-19772, the MBRS-RISE Program at EPCC, Grant Number R25 GM060424, and Texas AgriLife Research.

${ }^{1}$ To whom reprint requests should be addressed; e-mail gniu@ag.tamu.edu.
}

gation water. High soil salinity leads to poor germination, delays stand establishment, and reduces subsequent growth and yield of chile peppers and onion (Corgan et al., 2000; Flynn et al., 2002; Phillips, 2003). Seed germination and seedling emergence are critical growth stages for successful stand establishment, which impacts ultimate crop yields. Anecdotal observation indicated that it is more difficult for chile pepper seeds to germinate and establish in mineral soils compared with commercial potting mix. Elevated soil salinity and/or inadequate water supply can further reduce seedling establishment.

In furrow-irrigated croplands, a common problem with saline water and soils for vegetable production is high seedling mortality (Miyamoto et al., 1986). Soil salinity at or near the soil surface increases exponentially with time when saline water is used for irrigation (USDA Staff, 1954). Miyamoto et al. (2010) reported that seed germination, seedling emergence, and seedling growth of onions were affected by soil property, salinity of irrigation water, and irrigation method. The dynamics of salt movements and distribution in various soils are poorly understood.

Chile peppers (Capsicum annuum) are important vegetables in the southwestern states of the United States and in many other countries of the world. Peppers are considered moderately sensitive to salt stress (Maas and Hoffman, 1977; Pasternak and Malach, 1994). Yield reduction of peppers begins when the electrical conductivity (EC) of saturated soil extraction is greater than 1.5 $\mathrm{dS} \cdot \mathrm{m}^{-1}$ (Maas and Hoffman, 1977). However, limited recent studies of mostly bell peppers have indicated that some genotypes are more tolerant to salinity than others (Aktas et al., 2006; Chartzoulakis and Klapaki, 2000). The objectives of this study were to quantify 1) the effect of salinity of irrigation water and soil type on seedling emergence in two soil types; and 2) the relative tolerance of four commercial pepper varieties belonging to four botanical types, New Mexico long green, jalapeño, cayenne, and bell pepper, by growing them in commercial potting mix and irrigating the seedlings with saline solutions at various salinities.

\section{Materials and Methods}

Seedling emergence (Expt. 1). Two soils were used: 1) Blue Point loamy sand, which is characterized as structureless, loose when dry, rapidly drained, moderately alkaline, and calcareous; and 2) Harkey silt loam, which is calcareous and sandier than most alluvial soils of the Rio Grande Valley (Miyamoto et al., 2010). Blue Point loamy sand, similar to Vinton loamy sand, was collected from the south side of the El Paso Research Center property. Harkey silt loam, which is used extensively for irrigated crop production and mostly under surface irrigation in the middle Rio Grande Valley, was collected from a farm field located in Socorro, TX. These soils were air-dried, crushed, and passed through a 4 $\mathrm{mm}$ screen. Two inch square pots $(243 \mathrm{~mL})$ with holes were filled with either loamy sand soil or silt loam soil. To prevent soil loss, a Whatman filter paper was placed at the bottom of the pot.

Four commercial pepper varieties, namely, 'NuMex Joe E. Parker' (New Mexico long green), 'NuMex Nematador' (cayenne), 'NuMex Primavera' (jalapeño), and 'Jupiter' (bell), were used in this study. Six seeds were sown per pot $0.5 \mathrm{~cm}$ below the soil surface. Thirty-two pots, eight pots per cultivar, were placed in one tray. There were four trays per treatment. Trays were subirrigated with saline solutions daily by placing them in a shallow flat-bottomed large container with dimensions of $130 \times 70 \times 18 \mathrm{~cm}$ to mimic 
furrow irrigation. The initial soil salinities analyzed by saturated extraction according to USDA Staff (1954) were $0.8 \mathrm{dS} \cdot \mathrm{m}^{-1}$ and 0.9 $\mathrm{dS} \cdot \mathrm{m}^{-1}$ for loamy sand and silt loam soils, respectively. Three saline solutions at EC of 0.9 (tap water), 3.0, and $6.0 \mathrm{dS} \cdot \mathrm{m}^{-1}$ were prepared by adding sodium chloride $(\mathrm{NaCl})$, magnesium sulfate $\left(\mathrm{MgSO}_{4} \cdot 7 \mathrm{H}_{2} \mathrm{O}\right)$, and calcium chloride $\left(\mathrm{CaCl}_{2}\right)$ to tap water at a $87: 8: 5$ ratio on a weight basis.

The experimental design was a split-split plot with saline solution as the main plot, soil types the subplot, and cultivars as the subsubplot. There were four replications per treatment with eight subsamples. Emergence was recorded every 2 to $3 \mathrm{~d}$. The soil salinity of the top 1-cm soil layer was analyzed at the end of the experiment. Because few seedlings emerged at salinity levels of 3.0 and 6.0 $\mathrm{dS} \cdot \mathrm{m}^{-1}$, statistical analysis was conducted for the final emergence percent and soil salinity of the top soil layer at the end of the experiment between the two soil types by $t$ test. The details of the soil analysis procedure are described subsequently in Expt. 2.

Seedling emergence (Expt. 2). A second experiment was conducted to repeat the emergence test by lowering the salinity levels of the irrigation water to 0.0 [reverse osmosis (RO) water], $0.9 \mathrm{dS} \cdot \mathrm{m}^{-1}$ (tap water), or 1.5 $\mathrm{dS} \cdot \mathrm{m}^{-1}$ (saline solution). The loamy sand soils were collected again 4 months later from the same site and the initial soil salinity was 1.6 $\mathrm{dS} \cdot \mathrm{m}^{-1}$ (USDA Staff, 1954); that is, the initial soil salinity of loamy sand was higher than that in Expt. 1. The same silt loam collected for Expt. 1 was used for Expt. 2. Seedling emergence was recorded every 2 to $3 \mathrm{~d}$. The average day/night greenhouse temperatures during these experiments were 23.6/17.0 ${ }^{\circ} \mathrm{C}$. The experimental design for seedling emergence was identical to that of Expt. 1. Because the time course of emergence percent was presented, no statistical analysis was conducted.

Because salt was significantly accumulated at the top soil layer in Expt. 1, 20 additional pots per treatment without seed were prepared for soil samplings every week (four pots per week for 5 weeks) for soil salinity analysis to avoid disturbing seed germination and seedling emergence. Furthermore, to investigate the effect of irrigation method on salt accumulation at the top soil layer, additional flats with pots filled with both soil types without seed were included and irrigated with tap water using a mist head to mimic sprinkler irrigation.

The soil salinity of the top 1-cm layer of the pots without seed was analyzed for four pots per treatment (four replications) on a weekly basis, including the overhead-irrigated pots. The soil sampling procedure was as follows: cut the pot lengthwise along one side of the pot and pull the pot apart to expose the soil profile and mark the top centimeter of the soil surface. A piece of scratch paper was placed underneath the pot to collect the cut soil. The top soil layer was sliced using a spatula at the measured mark making sure the slice was even at all sides of the pot. The moist soil was then collected and placed into a pre-labeled paper bag and dried in an oven at $65{ }^{\circ} \mathrm{C}$ for soil salinity and $\mathrm{pH}$ analysis (USDA Staff, 1954). The extracted solutions were diluted by adding de-ionized water to obtain the actual EC whenever the EC exceeded $20 \mathrm{dS} \cdot \mathrm{m}^{-1}$. The EC and $\mathrm{pH}$ of the extracted solutions were determined using salinity and $\mathrm{pH}$ meters (Model B-173; Horiba, Ltd., Kyoto, Japan).

The effects of soil type (loamy sand and silt loam), salinity of irrigation water (RO,
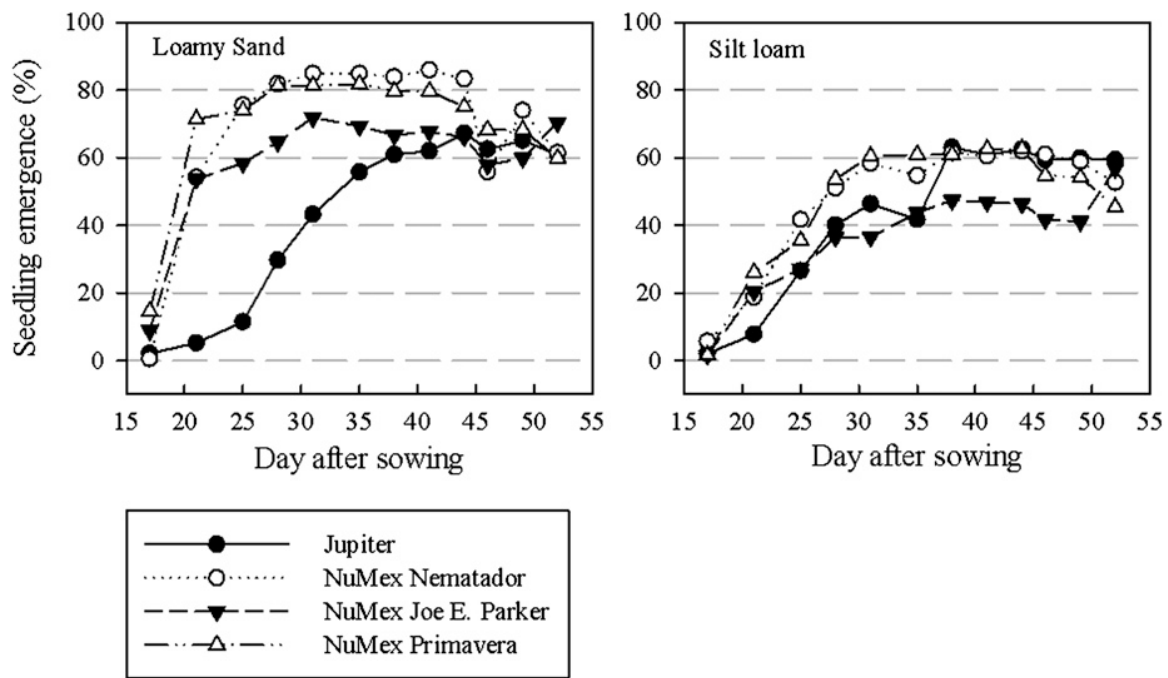

Fig. 1. Seedling emergence percent (Expt. 1) of four peppers, 'Jupiter' (bell), 'NuMex Nematador' (cayenne), 'NuMex Joe E. Parker' (long green), and 'NuMex Primavera' (jalapeño), in loamy sand and silt loam soils irrigated with tap water with electrical conductivity (EC) of $0.9 \mathrm{dS} \cdot \mathrm{m}^{-1}$. No seedlings emerged when saline water at EC of 3.0 and $6.0 \mathrm{dS} \cdot \mathrm{m}^{-1}$ was used (data not shown).
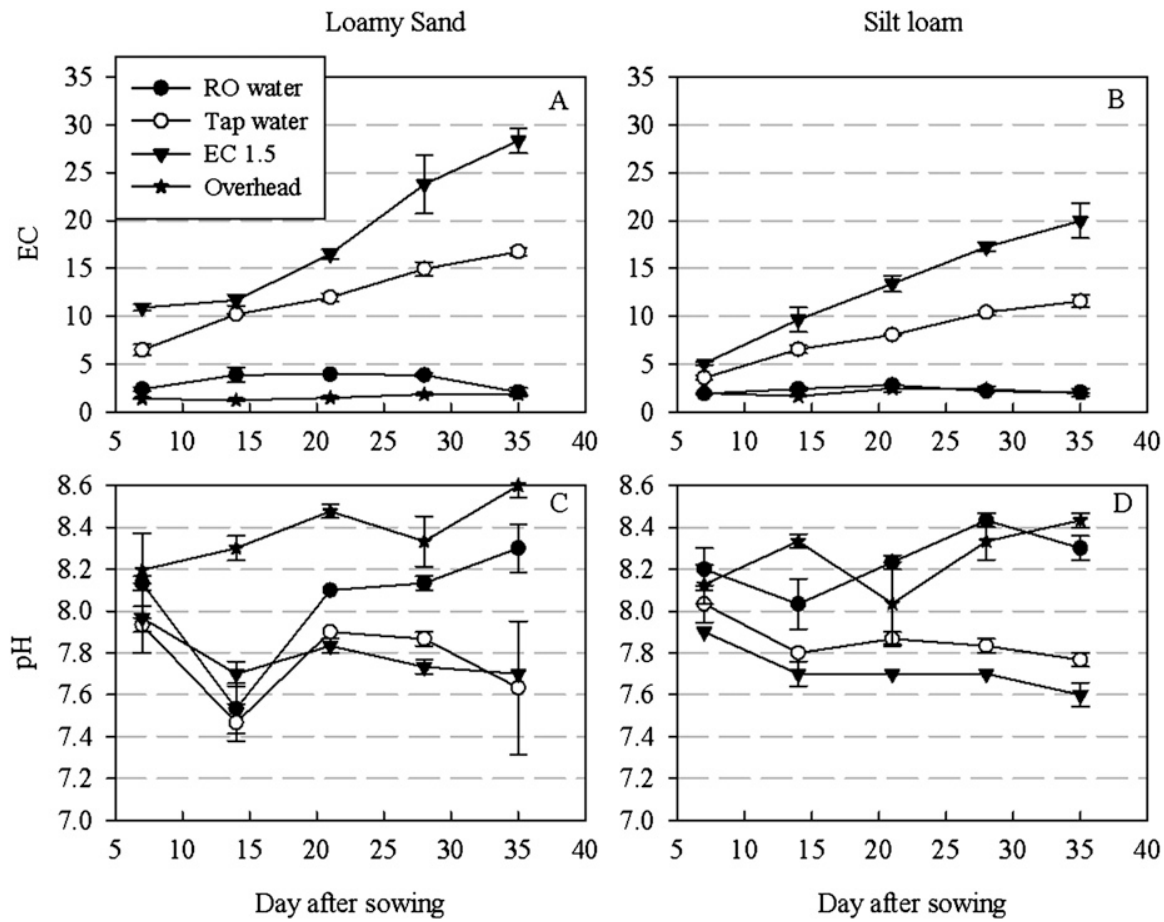

Fig. 2. (A-D) Soil salinity and pH (Expt. 2) of the top 1-cm layer analyzed through saturation extraction when subirrigated with reverse osmosis (RO) water, tap water at electrical conductivity (EC) of 0.9 $\mathrm{dS} \cdot \mathrm{m}^{-1}$ or saline solution at EC of $1.5 \mathrm{dS} \cdot \mathrm{m}^{-1}$, or overhead irrigated with tap water. Vertical bars represent $\operatorname{SES}(\mathrm{n}=4)$. 
Hort., Bellevue, WA) and germinated in a mist bench in the greenhouse. Forty days after sowing, seedlings were transplanted to plastic pots $(1.8 \mathrm{~L})$, one seedling per pot. Instead of using mineral soils, Sunshine Mix No. 4 (SunGro Hort.) was used in this experiment to rapidly screen the relative salt tolerance of the four pepper types. Three weeks after transplanting, when the seedlings had 11 to 13 true leaves and were 15 to $17 \mathrm{~cm}$ in height, saline water irrigation treatments were initiated. Ten uniform seedlings per treatment for each cultivar were selected. Saline solutions at EC of 1.4 (control, nutrient solution), 2.1, 2.9, 3.5, and $4.2 \mathrm{dS} \cdot \mathrm{m}^{-1}$ were prepared by adding $\mathrm{NaCl}, \mathrm{MgSO}_{4} \cdot 7 \mathrm{H}_{2} \mathrm{O}$, and $\mathrm{CaCl}_{2}$ to a nutrient solution. The nutrient solution was prepared by adding $0.5 \mathrm{~g} \cdot \mathrm{L}^{-1}$ of 20N-8.6P-16.7K (Peters 20-20-20; Scotts, Allentown, PA) to tap water. The major ions in the tap water were $\mathrm{Na}^{+}, \mathrm{Ca}^{2+}, \mathrm{Mg}^{2+}, \mathrm{Cl}^{-}$, and $\mathrm{SO}_{4}{ }^{2-}$ at 184, 52.0, 7.5, 223.6, and 105.6 $\mathrm{mg} \cdot \mathrm{L}^{-1}$, respectively. Plants were irrigated with $1 \mathrm{~L}$ treatment solution every time through the medium surface, which corresponded to $\approx 45 \%$ leaching fraction. Irrigation intervals were determined according to plant water use, which was estimated gravimetrically, and the environmental conditions to prevent overwatering and water stress. The average daily greenhouse temperatures during this experimental period were maintained at $23.8 \pm 0.9$ ${ }^{\circ} \mathrm{C}$ and daily light integral of the photosynthetically active radiation measured by a quantum sensor (Model QSO-SUN; Apogee Instruments, Inc., Logan, UT) was $22.4 \pm 2.3$ $\mathrm{mol} \cdot \mathrm{m}^{-2} \cdot \mathrm{d}^{-1}$.

The experiment was a split-plot design with saline solution as the main plot and cultivar the subplot with 10 replications (10 plants per treatment). Five weeks after saline irrigation treatments, six plants out of 10 were randomly harvested. Shoots were severed at the medium surface. Shoots were separated into leaves and stems and dry weights were determined after oven-drying at $70{ }^{\circ} \mathrm{C}$ to constant weight. The salinity of leachate was measured three times during the course of the 5-week experiment on four pots per treatment using a pour-through method (Wright, 1986). Specifically, $50 \mathrm{~mL}$ of RO water was added to the pot surface $1 \mathrm{~h}$ after irrigation when gravity drainage was complete. Leachate was collected and analyzed for $\mathrm{EC}$ and $\mathrm{pH}$ using salinity and $\mathrm{pH}$ meters (Model B-173; Horiba, Ltd.).

Data were analyzed by a two-way ANOVA using PROC GLM (SAS Institute, 2002). Linear and quadratic regressions between dry weight and salinity of irrigation water were performed. For the differences among the salinity treatments on seedling growth, Student-Newman-Keuls multiple comparisons were performed.

\section{Results and Discussion}

Seedling emergence (Expt. 1). The salinity of the top 1-cm soil layer at the end of the experiment ( $53 \mathrm{~d}$ after sowing) was $16.6 \pm 2.3$ $\mathrm{dS} \cdot \mathrm{m}^{-1}$ and $7.7 \pm 0.7 \mathrm{dS} \cdot \mathrm{m}^{-1}$ for loamy sand and silt loam, respectively, when subirrigated with tap water $\left(0.9 \mathrm{dS} \cdot \mathrm{m}^{-1}\right)$. The salinities of the top soil layers for the other two salinity treatments were greater than $20 \mathrm{dS} \cdot \mathrm{m}^{-1}$ and not analyzed in this experiment.

No seedlings emerged when soils were subirrigated with two high saline solutions ( 3.0 or $6.0 \mathrm{dS} \cdot \mathrm{m}^{-1}$ ), regardless of soil type or cultivar. Therefore, only results of seedlings subirrigated with tap water are presented (Fig. 1). The final emergence percent was higher in loamy sand than silt loam $(P=$ $0.0002)$ regardless of pepper type. Seedlings started to emerge between the second and

Loamy Sand
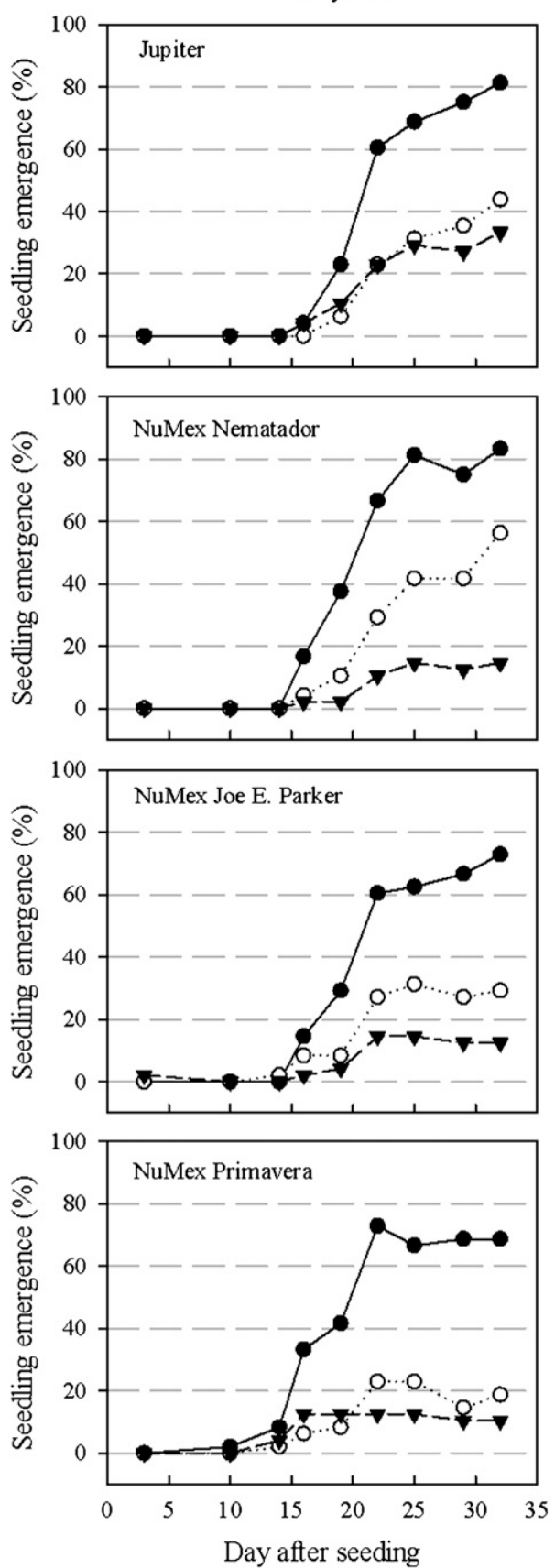

third weeks after sowing. In loamy sand, 'Jupiter' had the slowest emergence followed by 'NuMex Joe E. Parker'. The differences in emergence percent among the four tended to be smaller over time. Forty-five d after sowing, there were no differences in emergence percent among the four, because some seedlings of 'NuMex Nematador' and 'NuMex Primavera' died as a result of the high salinity at the soil surface. The emergence percent 3 weeks after sowing for all cultivars except for 'Jupiter' tended to be lower in silt loam soil compared with loamy sand. After 5 weeks in silt loam, the final percent of emergence was
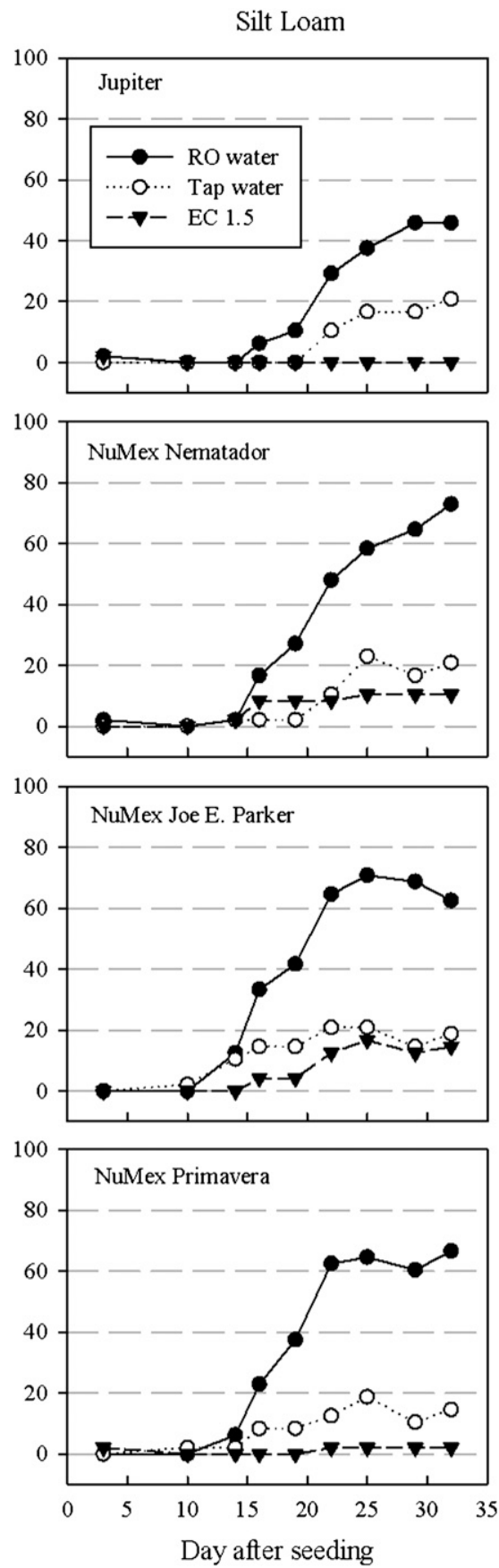

Fig. 3. Seedling emergence rate (\%) (Expt. 2) of four peppers, 'Jupiter', 'NuMex Nematador', 'NuMex Joe E. Parker', and 'NuMex Primavera', in loamy sand and silt loam soils subirrigated with reverse osmosis (RO) water, tap water at electrical conductivity (EC) of $0.9 \mathrm{dS} \cdot \mathrm{m}^{-1}$, or saline solution at EC of $1.5 \mathrm{dS} \cdot \mathrm{m}^{-1}$. 
lower for 'NuMex Joe E. Parker', but there were no differences in the final emergence percent among the four peppers.

Seedling emergence (Expt. 2). Interactive effects of salinity and soil type were observed for soil $\mathrm{pH}$ and salinity of the top $1-\mathrm{cm}$ soil layer. Salinity of the top soil layer increased linearly with time for both tap and saline solutions in both soils when subirrigated, whereas it was relatively stable at EC of less than $5 \mathrm{dS} \cdot \mathrm{m}^{-1}$ subirrigated with RO water or overhead irrigated with tap water (Fig. 2AB). For overhead irrigation in loamy sand soil, the soil salinity at the top soil layer was slightly lower than that when irrigated with RO water (Fig. 2A). In silt loam soil irrigated with overhead tap water, the soil salinity of the top layer was similar to that when subirrigated with RO water (Fig. 2B). Salt accumulation at the top soil layer was greater in loamy sand than silt loam when subirrigated with tap and saline water, similar to Expt. 1. This result is consistent with observations by Miyamoto et al. (2010) whereby it was reported that salts can accumulate in the surfaces of poorly drained soils as a result of evaporation of saline water, which moves to the surface through capillary action. In the current study, salt accumulation in the surfaces of the silt loam soil was less dramatic. The $\mathrm{pH}$ was generally higher when subirrigated with RO water and overhead irrigated with tap water compared with tap and saline water from the third week after sowing (Fig. 2C-D). The soil $\mathrm{pH}$ generally decreased when soil salinity increased in both soil types.

Seedling emergence started between 21 and $28 \mathrm{~d}$ after sowing in both soil types for all pepper types (Fig. 3). When subirrigated with RO water, emergence percent was higher in loamy sand than silt loam for 'Jupiter', but the differences in emergence percent for other pepper types between the two soil types were smaller compared with 'Jupiter'. When subirrigated with tap water, only 'Jupiter and 'NuMex Nematador' had more than $40 \%$ emergence in loamy sand; the other pepper types had lower emergence percents, regardless of soil type. When subirrigated with saline solution at $1.5 \mathrm{dS} \cdot \mathrm{m}^{-1}$, emergence was lower than $20 \%$, except for 'Jupiter' in loamy sand. Few seedlings of 'NuMex Primavera' and 'Jupiter' emerged with saline solution in silt loam.

Emergence percent was generally higher in loamy sand than silt loam, although salt accumulation at the top soil layer was greater in loamy sand than silt loam, which may be the result of soil permeability. Soil permeability influences salt accumulation and distribution in the root zone and therefore results in differences in plant responses to salinity (Shannon et al., 1994). Under subirrigation or furrow irrigation, seedling establishment of the selected four pepper types in soils containing salts, in this case, with $\mathrm{EC}_{\mathrm{e}}$ of 1.6 and $0.9 \mathrm{dS} \cdot \mathrm{m}^{-1}$ for loamy sand and silt loam, respectively, would be challenging unless the irrigation water contains little salts, which is not likely. Overhead irrigation such as with a sprinkler may help seedling establishment resulting from lower soil salinity at top soil layer, which is evidenced in this experiment. Miyamoto et al. (2010) reported that onion seedling emergence and growth were enhanced by overhead irrigation compared with subirrigation in loamy land. Therefore, irrigation with an overhead sprinkler, leaching salts, or increasing seeding density may be options to improve seedling establishment in salt-affected fields and with low-quality irrigation water.

Seedling growth (Expt. 3). The leachate $\mathrm{EC}$ and $\mathrm{pH}$ were unaffected by pepper types. Therefore, data were pooled across the four peppers. The leachate EC, averaged from three measurements, was $2.3,3.6,5.0,5.3$, and $6.0 \mathrm{dS} \cdot \mathrm{m}^{-1}$ for the treatments 1.4 (control, nutrient solution), 2.1, 2.9, 3.5, and 4.2 $\mathrm{dS} \cdot \mathrm{m}^{-1}$, respectively (data not shown). The $\mathrm{pH}$ values of the leachate for all treatments were stable, ranging from 6.19 to 6.35 .

The dry weight (DW) of stems, leaves, and shoots for all four pepper types were reduced by the elevated salinity of irrigation water, but the reduction varied among pepper types (Table 1). The DW reduction at 4.2 $\mathrm{dS} \cdot \mathrm{m}^{-1}$ compared with control was higher in stems than in leaves for 'Jupiter' (31\%), 'NuMex Joe E. Parker' (25\%), and 'NuMex Primavera' (35\%). For 'NuMex Nematador', DW of both leaves and stems had similar reductions $(18 \%$ and $20 \%)$ in $4.2 \mathrm{dS} \cdot \mathrm{m}^{-1}$ compared with control. By comparing 4.2 $\mathrm{dS} \cdot \mathrm{m}^{-1}$ with control, total shoot DW was reduced by $32 \%$ in 'NuMex Primavera', $25 \%$ in 'Jupiter', and $18 \%$ in 'NuMex Joe E. Parker' and 'NuMex Nematador'. Therefore, based on growth, 'Jupiter' and 'NuMex Primavera' were more sensitive to salinity compared with 'NuMex Joe E. Parker' and 'NuMex Nematador', which was in agreement with the emergence results in Expt. 2 with saline water irrigation in silt loam soil. However, the differences in seedling emergence and growth in response to elevated salinity were small among the four peppers.

In another separate salt tolerance study with 20 chile peppers, 'NuMex Joe E. Parker', 'NuMex Nematador', and 'NuMex Primavera' seedlings had significant growth

Table 1. Dry weight of stem, leaves, and shoots of 'Jupiter' (bell), 'NuMex Nematador' (cayenne), 'NuMex Joe E. Parker' (long green), and 'NuMex Primavera' (jalapeño) pepper seedlings irrigated with saline solutions at 0.9 (control), $2.1,2.9,3.4$, or $4.2 \mathrm{dS} \cdot \mathrm{m}^{-1}$.

\begin{tabular}{|c|c|c|c|c|c|c|c|c|}
\hline & & \multicolumn{7}{|c|}{ Salinity of irrigation solution } \\
\hline & & 0.9 & 2.1 & 2.9 & 3.4 & 4.2 & $\mathrm{~L}$ & Q \\
\hline \multirow[t]{3}{*}{ Jupiter } & Stem & $7.9 \mathrm{a}^{\mathrm{z}}$ & $8.0 \mathrm{a}$ & $7.1 \mathrm{ab}$ & $6.6 \mathrm{~b}$ & $5.6 \mathrm{c}$ & $* * * \mathrm{y}$ & $* * *$ \\
\hline & Leaves & $15.5 \mathrm{a}$ & $16.4 \mathrm{a}$ & $15.9 \mathrm{a}$ & $15.1 \mathrm{a}$ & $12.9 \mathrm{~b}$ & $* * *$ & $* * *$ \\
\hline & Shoot & $23.4 \mathrm{a}$ & $24.5 \mathrm{a}$ & $23.0 \mathrm{a}$ & $21.8 \mathrm{a}$ & $18.4 \mathrm{~b}$ & $* * *$ & $* * *$ \\
\hline \multirow[t]{3}{*}{ Nematador } & Stem & $13.6 \mathrm{a}$ & $11.9 \mathrm{a}$ & $12.1 \mathrm{a}$ & $10.9 \mathrm{a}$ & $10.9 \mathrm{a}$ & $*$ & NS \\
\hline & Leaves & $14.6 \mathrm{a}$ & $14.1 \mathrm{a}$ & $14.3 \mathrm{a}$ & $13.1 \mathrm{a}$ & $12.1 \mathrm{a}$ & * & NS \\
\hline & Shoot & $28.2 \mathrm{a}$ & $26.1 \mathrm{a}$ & $26.3 \mathrm{a}$ & $24.0 \mathrm{a}$ & $23.0 \mathrm{a}$ & $* *$ & NS \\
\hline \multirow[t]{3}{*}{ Joe E. Parker } & Stem & $13.5 \mathrm{a}$ & $14.5 \mathrm{ab}$ & $13.9 \mathrm{ab}$ & $10.9 \mathrm{~b}$ & $10.9 \mathrm{~b}$ & $* *$ & NS \\
\hline & Leaves & $15.9 \mathrm{a}$ & $16.5 \mathrm{a}$ & $16.0 \mathrm{a}$ & $14.4 \mathrm{a}$ & $14.9 \mathrm{a}$ & NS & NS \\
\hline & Shoot & $29.4 \mathrm{a}$ & $31.1 \mathrm{a}$ & $29.9 \mathrm{a}$ & $25.2 \mathrm{a}$ & $25.8 \mathrm{a}$ & $*$ & NS \\
\hline \multirow[t]{3}{*}{ Primavera } & Stem & $7.6 \mathrm{a}$ & $8.4 \mathrm{ab}$ & $7.5 \mathrm{ab}$ & $5.8 \mathrm{bc}$ & $5.4 \mathrm{c}$ & $* *$ & $*$ \\
\hline & Leaves & $11.4 \mathrm{a}$ & $12.4 \mathrm{a}$ & $12.2 \mathrm{ab}$ & $9.8 \mathrm{bc}$ & $8.8 \mathrm{c}$ & $* *$ & $* *$ \\
\hline & Shoot & $19.0 \mathrm{a}$ & $20.8 \mathrm{a}$ & $19.6 \mathrm{a}$ & $15.6 \mathrm{~b}$ & $12.4 \mathrm{~b}$ & $* *$ & $* *$ \\
\hline
\end{tabular}

${ }^{\mathrm{z}}$ Means with same letters in the same row are not significantly different among treatments at $P=0.05$. y*,**,***, Ns indicates significant and nonsignificant at $P=0.05,0.01$, or 0.001 , respectively. $\mathrm{L}$ and $\mathrm{Q}=$ linear and quadratic regression between growth parameters and salinity treatment. 
water. Based on seedling growth, bell pepper 'Jupiter' and jalapeño 'NuMex Primavera' may be more sensitive to salinity than long green 'NuMex Joe E. Parker' and cayenne 'NuMex Nematador', but the differences in salt tolerance among the four peppers were small.

\section{Literature Cited}

Aktas, H., K. Abak, and I. Cakmak. 2006. Genotypic variation in the response of pepper to salinity. Sci. Hort. 110:260-266.

Chartzoulakis, K. and G. Klapaki. 2000. Response of two greenhouse pepper hybrids to $\mathrm{NaCl}$ salinity during different growth stages. Sci. Hort. 86:247-260.

Corgan, J., M. Wall, C. Cramer, T. Sammis, B. Lewis, and J. Schroeder. 2000. Bulb onion culture and management. New Mexico State University, Cooperative Extension Service, Circular 563.
Flynn, R., R. Phillips, A. Ulery, R. Kochevar, L. Liess, and M. Villa. 2002. Chile seed germination as affected by temperature and salinity. New Mexico Chile Task Force, New Mexico State University, Cooperative Extension Service, Report 2.

Maas, E.V. and G.J. Hoffman. 1977. Crop salt tolerance - Current assessment. J. Irrig. Drain. Div. 103:115-134.

Miyamoto, S., G. Niu, and I. Martinez. 2010. Salinity and specific ion effects on onion establishment in relation to disposal of desalting concentrates. Desalination and Water Treatment 16:381-392.

Miyamoto, S., K. Piela, and J. Petticrew. 1986. Seedling mortality of several crops induced by root, stem or leaf exposure to salts. Irrig. Sci 7:97-106.

Pasternak, D. and Y.D. Malach. 1994. Crop irrigation with saline water, p. 599-622. In: Pessarakli, M. (ed.). Handbook of plant and crop stress. Marcel Dekker, New York, NY.
Phillips, R. 2003. Chile pepper growers' notes. New Mexico State University Cooperative Extension Service, New Mexico Chile Task Force Report 10

Sanogo, S. 2004. Response of chile pepper to Phytophthora capsici in relation to soil salinity. Plant Dis. 88:205-209.

SAS Institute. 2002. SAS/STAT software, Version 9.1. SAS Institute, Cary, NC.

Shannon, M.C., C.M. Grieve, and L.E. Francois. 1994. Whole-plant response to salinity, p. 199 244. In: Wilkinson, R.E. (ed.). Plant environment interaction. Marcel Dekker, New York, NY.

USDA Staff. 1954. Diagnosis and improvement of saline and alkaline soils. USDA Agric. Handbook No. 60. In: Richards, L.A. (ed.). U.S. Gov. Print. Office, Washington, DC.

Wright, R.D. 1986. The pour-through nutrient extraction procedure. HortScience 21:227229. 